CIRJE-F-986

\title{
Infrastructure and Well-being: Employment Effects of Jamuna Bridge in Bangladesh
}

\author{
Minhaj Mahmud \\ BRAC University \\ Yasuyuki Sawada \\ The University of Tokyo
}

August 2015

CIRJE Discussion Papers can be downloaded without charge from:

http://www.cirje.e.u-tokyo.ac.jp/research/03research02dp.html

Discussion Papers are a series of manuscripts in their draft form. They are not intended for circulation or distribution except as indicated by the author. For that reason Discussion Papers may not be reproduced or distributed without the written consent of the author. 


\title{
Infrastructure and Well-being:
}

\section{Employment Effects of Jamuna Bridge in Bangladesh}

\author{
by \\ Minhaj Mahmud \\ BRAC Institute of Governance and Development \\ BRAC University, Bangladesh \\ Email: minhajmahmud@gmail.com. \\ $\&$ \\ Yasuyuki Sawada \\ Faculty of Economics, University of Tokyo, Japan \\ Email: sawada@e.u-tokyo.ac.jp. \\ Corresponding author
}

\begin{abstract}
We evaluate the impact of the Jamuna multipurpose bridge, the largest physical infrastructure in Bangladesh, on employment opportunities. We particularly focus on labour market integration effects using survey data that provides information on current and retrospective assessments of household situation in two adjacent districts connected by the bridge. Using a quasi-experimental framework of the canonical difference-in-difference regression methodology, we analyse the impact of this infrastructure on employment and job transition patterns. We find that, along with decreasing household unemployment, the bridge construction facilitated farm to non-farm shift of employments. Also the treatment effects are heterogeneous across age, gender and education level.
\end{abstract}

Keywords: infrastructure, jobs, occupational choices, difference-in-difference, evaluation, Bangladesh

JEL Code: H54; J40; J62; O1; O18

Acknowledgements: We would like to thank Dr. Mahabub Hossain, Advisor, BRAC, for allowing us to use the data from the BRAC-RED evaluation study, "the long-term social impact assessment of Jamuna Multipurpose Bridge in Bangladesh." We would like to thank Abhijit Banerjee, Akio Hosono, Naohiro Kitano, Megumi Muto, Shanthi Nataraj, Ichiro Tambo, and Yasuyuki Todo as well as seminar participants at the Planning Commission of Bangladesh in Dhaka, Asian Development Bank Institute in Tokyo, JICA Research Institute in Tokyo, and the "Poor Economics" in Tokyo workshop participants at University of Tokyo for helpful comments. We also express our gratitude to International Growth Centre (IGC) and JSPS for financial assistance. Usual disclaimer applies. 


\section{Introduction}

Physical infrastructure is seen as an essential precondition for industrialization and economic development (Murphy, Shleifer, \& Vishny 1989). Both macroeconomic endogenous growth literature (Barro 1990; Futagami, Morita, \& Shibata, 1993) as well as empirical studies (Easterly and Rebelo 1993; Lipton and Ravallion 1995; Jimenez 1995; Canning and Bennathan 2000; Esfahani and Ramirez 2003; Canning and Pedroni 2008; Calderón, MoralBenito, \& Servén 2014) observed that development of physical infrastructure improves an economy's long-term production and income levels. For example, Hulten et al (2006) found that in India, from 1972 to 1992, highways and electricity accounted for almost half of the growth of the Solow residuals of manufacturing industries. Other studies have focused on the positive productivity effects of physical infrastructure in rural and agricultural sectors (Jimenez, 1995; Fan and Zhang, 2004; Zhang and Fan, 2004). These suggest that infrastructure is likely to reduce poverty by enhancing growth, given that strong positive correlation between income growth and poverty reduction has been widely observed (see Besley and Burgess, 2003; Dollar and Kraay, 2002, Ravallion, 2001).

Physical infrastructure consists of economic infrastructure such as telecommunications, roads, irrigation and electricity; and social infrastructure such as water supply, sewage systems, hospitals and school facilities. A number of micro studies have shown that the development of these economic infrastructure is one of the indispensable components of poverty reduction. ${ }^{1}$ While these studies are insightful in uncovering the role of

\footnotetext{
${ }^{1}$ These include Datt and Ravallion (1998) on state-level poverty in India, Van de Walle (1996) on the poverty reduction effect of irrigation infrastructure in Vietnam, Jalan and Ravallion (2003) on water supply systems, Lokshin and Yemtsov $(2004,2005)$ on the poverty reduction effect of community-level infrastructure improvement projects on water supply systems in Georgia, and Duflo and Pande (2007) on the role of dams in reducing poverty in India. In addition, Brockerhoff and Derose (1996) and Jalan and Ravallion (2003)
} 
infrastructure in reducing poverty, to the best of our knowledge, only few studies explicitly approach "structures" of this correlation. One of such important channels should be the job transformation and non-farm employment effects of improved infrastructure because most of labour market imperfections and resulting slow structural transformations could be attributed to binding market frictions (Banerjee and Newman, 1993) which can be relaxed by infrastructure development. ${ }^{2}$ Interestingly impacts of large infrastructure that decrease (labour) market transaction costs have been hitherto unexplored. We aim to fulfil this gap in literature, which has significant development policy implication.

In this study, we focus on the impact of the Jamuna multipurpose bridge (JMB), built in 1998 as the largest infrastructure in Bangladesh, on labour market integration. JMB connects the eastern and western part of the country, through the capital Dhaka, which presumably facilitate economic integration and development of the whole economy (Hossain, Sen, and Sawada, 2012). There are several existing evaluation reports of JMB (e.g. Luppino et al. 2004; Ghosh et al. 2010). ${ }^{3}$ The first study, based on CGE modelling approach, show a reduction in poverty in Bangladesh due to installation of JMB. The second study based on survey findings also suggested that project affected people were able to manage to restore their livelihood during the post-project time. Also, using household panel data, Bayes (2007) suggests that the construction of the bridge 'went a long way in reducing the poverty' by increasing farmers' income through high value crops.' However, rigorous evaluation using investigate the role of water supply and public health systems. Jacoby (2000), Gibson and Rozelle (2003), and Jacoby and Minten (2009) investigate the effectiveness of road and transportation infrastructure.

2 There are several important studies related to this topic such as Fafchamps and Shilpi (2005), Jacoby and Minten (2009), and Bryan, Chowdhury, and Mobarak (2014),

3 The project completion report by ADB (2000) concluded that: "The Project has been satisfactorily implemented and is rated highly successful. The main objective of the Project has been met, connecting the eastern and western parts of the country, separated by the Jamuna River, through a fixed link. The Project will stimulate economic growth by facilitating the transport of passengers and freight and the transmission of electricity, natural gas, and telecommunications across the Jamuna River ore economically and efficiently." 
experimental or quasi experimental approach to establish causality particularly with regards to bridge's impact on labour market is still missing. ${ }^{4}$ While random placement of infrastructure can be very difficult, if such placement is beyond human manipulation then it provides researchers a natural experimental setting similar to DiNardo (2008), in which affected people can be assigned to treatment and control groups to analyse the impact. That is, experimental or quasi-experimental approach, that can address the selection bias, can establish causal impacts. ${ }^{5}$ For example, Gonzalez -Navarro and Quinana-Domeque (2012) provide the first randomized evaluation of street asphalting pavement on poverty reduction in Acayucan, Mexico.

We therefore follow the recent quasi-experimental literature (e.g., Duflo and Pande, 2007; Dinkelman 2011; Banerjee et al. 2012) to understand the causal impact of the bridge on employment in Bangladesh. For example, Duflo and Pande (2007) use quasi-experimental instrumental variable approach to study the impact of dams in India on poverty reduction using the river gradient variable as an instrument. We adopt a quasi-experimental framework of the canonical difference-in-difference regression methodology to analyse the impact of the bridge (JMB) on employment and job transition patterns in the adjacent districts. We find that, along with decreasing household unemployment, the bridge facilitated a shift from farm to non-farm employments. We also find that the treatment effects are heterogeneous across age, gender and education level.

\footnotetext{
${ }^{4}$ In terms of evaluating impacts of infrastructure, non-experimental studies tend to provide biased estimates of elasticity due to selection bias as infrastructure may be placed in areas where economic growth is expected and or hosting communities have appropriate capacities.

${ }^{5}$ See Sawada (2014) for a recent survey of experimental literature studying the impact of infrastructure. For studies that employ panel data fixed effect approach in studying infrastructure impact, see for example, Khandker et al (2009) on returns to road investment in Bangladesh and Sawada et al (2014) on impact of irrigation in Sri Lanka.
} 
The rest of this paper is organized as follows: Section 2 discusses the methodology and data. Section 3 discusses econometric analysis and results. Section 4 concludes the paper.

\section{Data and Methodology}

We analyse the JMB evaluation data collected by BRAC- Research and Evaluation Division (RED) (Ghosh et al., 2010). In 2009, BRAC-RED conducted an assessment evaluation study of JMB by surveying 1550 randomly selected project affected households in the adjacent Sirajganj and Tangail districts. The data set provides us various information on a total of 1,485 households (761 in Tangail; and 841 in Sirajganj). However, we particularly focus on the information about occupation and employment opportunity of these households for our purpose. In addition to the current information, the survey contains retrospective assessments of household's livelihood condition before the bridge construction. Since the pre-bridge information is collected ten years after the bridge construction there are implications of potential measurement error. We believe, however, use of retrospective information is less problematic in our setting at least for two reasons: First, we employ retrospective information on occupation which may be accurately recalled even after ten years. ${ }^{6}$ Second, since variables with potential recall errors are used for independent variables, and not for dependent variables, estimation biases due to measurement errors are likely to be minimalistic. While a variable with measurement errors enter as independent variables in a regression model, it is natural to be concerned about attenuation bias arising from measurement errors in retrospective data. However when the variable with errors is used as a

\footnotetext{
${ }^{6}$ In fact, comparing respondent reports with company records for a sample of workers from a large manufacturing firm in the US, Mathiowetz and Duncan (1988) found that time was not found to be the most important factor in producing retrospective response errors of unemployment.
} 
dependent variable, the errors will not cause estimation bias if the errors are mean zero random errors, albeit the non-classical measurement errors.

To analyse the impact of bridge, we can regard households in Sirajganj and Tangail districts as "treatment" and "control" groups, respectively. This is justified because the bridge improved accessibility of Sirajganj population to Dhaka dramatically although Tangail population were relatively unaffected by the bridge in terms of access to Dhaka. However, in terms of improved employment opportunity some impact might also be seen in Tangail, as reported by $18 \%$ of the respondents there. This implies that, while Sirajganj is more intensely treated; both districts ended up getting treated. ${ }^{7}$ Figure 1 (Maps 1 and 2) shows the location of the bridge as well as the survey locations, respectively. We also have detailed job category of each individual in the data set before and after JMB. We observed seven main job categories. This would allow us to construct a job transition matrix before and after JMB construction for each district. Thus we have considered Sirajganj (point B in Map 1) and Tangail (point A in Map 1) districts as "treatment" (or say, intensely treated) and "control" groups respectively, to evaluate the policy impact.

Accordingly, we adopt the canonical difference-in-difference regression approach to analyse the impact of the bridge on jobs. The Difference-in-difference model is one of the most important identification strategies in applied economics, which model measures the differences in outcome overtime for the treatment group in interest compared to the difference in outcome overtime for the control group in interest (see Angrist and Krueger 1999 and Bertrand, Duflo \& Mullainathan, 2004). A potential issue in our analysis is selection bias arising from endogenous choice of the bridge location. For example, if the location is selected according to the pre-bridge density of economic activities, then there will be an upward bias in estimating the treatment effect. However, the available evidence

\footnotetext{
7 The proportion of respondents who selected this answer choice is $18.53 \%$ and $22.54 \%$ for Tangail and Sirajganj districts respectively, and the proportion is $4.01 \%$ higher (t-statistics $=1.91$ ) among the treatment group.
} 
suggest that the bridge location has been decided mainly based on engineering reasons (AlHussain, Ansary, and Choudhury 2004). In 1985, the respective authority of the government of Bangladesh selected the site for the bridge, based on where the river flows in a relatively narrow belt and mostly in one channel, determined using satellite imagery and earlier bathymetric surveys. ${ }^{8}$ Hence, the policy treatment due to the bridge construction can be argued to be largely exogenous to surrounding people's characteristics.

\section{Covariate Balancing Tests}

To formally check the exogeneity of the bridge construction, we conduct balancing tests of observed pre-bridge covariates of the treatment and control group households. Specifically, we test a null hypothesis of the same mean values for four observed variables, age, education level, unemployment rate of the household head, and subjective income sufficiency index before the bridge construction, across treatment and control groups. Table 1 shows that there are no statistically-significant differences across the two groups in these four pre-bridge characteristics.

\section{Policy Effects}

Our data set provides information about households' assessment of both positive and negative aspects of JMB in terms of household welfare. It contains the survey respondents' assessments of (their) household benefit as a result of the bridge construction, whereby multiple response categories were used. We focus on one particular response category in our analysis i.e., expanding employment opportunities. In fact, Ghosh et al. (2010) observed that a considerable number of people reported that the construction of the bridge increased

\footnotetext{
${ }^{8}$ Reflecting this, the World Bank's project completion report stated that as to resettlement and rehabilitation issues, "people do not become entitled to support until they have actually been displaced by flooding or erosion, and the amount and location of this is wholly unpredictable" World Bank (2000).
} 
employment opportunity and that the property value (land price) went up in Tangail. However, in Sirajganj more people reported seeing $\mathrm{n}$ an increase in price of land and in employment and business opportunities. We can then construct a treatment indicator $d$ which takes 1(one) for Sirajgani (treatment group) and 0 (zero) for Tangail (control group). Thus we can set up a canonical difference-in-difference model to estimate the treatment effect as follows, whereby the dependent variable, $Y$, is "improvements in employment opportunities." In a difference-in-difference model only a single variable indicates treatment, i.e., the interaction variable between treatment group and the treatment period dummy variable:

$$
Y_{i t}=\alpha_{0}+\alpha_{1} T_{t}+\gamma d_{i}+\delta T_{t} \times d_{i}+u_{i}+\varepsilon_{i t},
$$

where $T$ is a time dummy; $u$ and $\varepsilon$ are household fixed effects and error term, respectively. The average treatment effects on the treated can be captured by estimating $\delta$. Let $\Delta$ shows a first order lag operator. Then we have a first-differenced version of the model (1) as follows:

$$
\Delta Y_{i t}=\alpha_{1}+\delta d_{i t}+\varepsilon^{d}{ }_{i t}
$$

Our estimation strategy is to estimate the treatment effect by estimating equation (2) by using OLS under a set of standard assumptions with a set of observed control variables, $X$. While it is unlikely that mass migrations have been induced by villages in Sirajganj, to mitigate bias arising from omitted variables, we also included village fixed effects, $u_{v}$. By doing so, we can also accommodate village specific un-parallel trends. Our final regression model is defined as follows:

$$
\Delta Y_{i t}=\alpha_{1}+\delta d_{i t}+X_{i t} \beta+u_{v}+\varepsilon^{d}{ }_{i t}
$$


To investigate the job transition patterns, we estimate a multinomial logit model of occupational transition. Our framework is that of an additive random-utility model in which a latent equation for utility for individual $i$ taking alternative $j$ at time $t$ is formulated as:

$$
V_{i j}=\alpha_{0 j}+\alpha_{1 j} T_{t}+\gamma_{j} d_{i}+\delta_{j} T_{t} \times d_{i}+X_{i t} \beta_{j}+u_{i t}
$$

This individual would take alternative $j$ when alternative $j$ has the highest utility of the alternatives, which is observed. It follows that Prob $\left(y_{i}=j\right)=\operatorname{Prob}\left(V_{i j}>V_{i k}\right)$ for all $k$. In equation (4), $\delta_{j}$ quantifies the choice-specific treatment effect of JMB in the non-linear difference-in-difference approach, which can be estimated by multinomial logit (MNL) model. By transferring the difference-in differences identification strategy to the latent variable, the non-linearity in the conditional expectation of the outcome is addressed. Here the latent non-linear index is contained in the interaction term that is the product of the group and time indicators, whereas the difference in difference usually referring to a difference in the differences between groups across times. As Puhani (2012) showed, the treatment effect in non-linear models is the cross difference of the observed outcome minus the cross difference of the potential non-treatment outcome, which equals the incremental effect of the interaction term coefficient in the index. To illustrate this, we have a non-linear differencein-difference model for each of the occupation choice: $E[Y \mid T, d, X]=\Gamma\left(\alpha_{0}+\alpha_{1} T+\gamma d+\right.$ $\delta T \times d+X \beta$ ) where $\Gamma$ is a distribution function. Then as Puhani (2012) showed, the treatment effects in the difference-in-difference model can be written as:

$$
E\left[Y^{1} \mid T=1, d=1, X\right]-E\left[Y^{0} \mid T=1, d=1, X\right]=\Gamma\left(\alpha_{0}+\alpha_{1}+\gamma+\delta+X \beta\right)-\Gamma\left(\alpha_{0}+\alpha_{1}+\gamma+X \beta\right) .
$$


This indicates that the treatment effect is the cross difference of the conditional expectation of the observed outcome $Y$ minus the cross difference of the conditional expectation of the counterfactual outcome $Y^{0}$, which can be simplified to the marginal effect of the coefficient of the interaction term, $T \times d$. The subsequent estimations will also incorporate heterogeneous treatment effects by age, gender, and education level.

\section{Econometric analysis and Results}

We adopted a linear probability approach to estimate the model of equation (3) using ordinary least square (OLS). Table 2 reports estimation results, whereby specification (1) shows the overall impact of JMB and specification (2) shows location specific treatment effects. The results indicate that JMB has a positive and significant employment improvement effects with or without an assumption of homogenous treatment effects. The results in specification (1) indicate that JMB increased possibility of employment expansion by $4 \%$ on average. The impact seems to be larger in the less adjacent areas (location \#2 and \#4) than the nearby location (location \#1), suggesting that there might be direct negative impacts of JMB due to relocation. The qualitative results are maintained if we control for direct impact of JMB through expansion of land-holding and transfers of monetary compensations due to relocation.

\section{Multinomial logit (MNL) results}

We estimate a model of equation (4) using the MNL model. Table 3 shows estimated coefficients as well as marginal effects calculated at the mean in brackets of a simple specification of MNL, in which we consider farming or fishing as the base occupation category for comparison. The estimated results show that the common treatment effect, $T \times d$, 
is not significant for any of the occupational category at the $5 \%$ of significance level although specification (3) for the business and trade job category shows a marginal negative impact.

Since estimation with a homogenous treatment assumption may mask important heterogeneity, we incorporate heterogeneous treatment effects with regards to age in Table 4, as well as gender and education level of respondents in Tables 5 and 6 . For age, we use the following age categories: 1) 21-30 years of age, 2) 31-50 years of age and 3) 51-71 years of age. We then investigate the differential treatment effects with respect to male and female (Table 5). In a final specification reported in Table 6, we incorporate specific treatment effects for the high education group in order to see heterogeneous effect arising from human capital.

In Table 4, we observe that being young (age 21 to 30) induce transition from farming to wage labourer in category (1). This means that younger people are more likely to switch from farming to more cash rewarding daily labour and trading occupation. We also observe that more young household members could be engaged in studying (student as an occupation in category (5)). We also observe treatment effects on productive age (age 31 to 50) people having less unemployment shown in category (7)-unemployment rate of this group decreased by around $16 \%$ points.

In Table 5, we adopted a specification allowing for further heterogeneity across genders. In this table, we find that these transition patterns among the young observed in Table 4 are rather male specific than female. JMB seems to induce the young male of age 21 to 30 to switch from farming or fishing to wage as well as business or trade occupations. However, in category (7), the effect of decreasing unemployment effects is found among female members of age $31-50$ years with $20 \%$ point decrease of unemployment rate.

Finally, in Table 6, we report heterogeneous treatment effects by education level. We define "high education group" as a group of people whose education level is equal to or 
above the higher secondary school level. In this specification, we clearly observe that the occupation transition effect of JMB from farming to day labourer is pronounced among uneducated male, and that the transition from farming to trading or commerce is concentrated among the educated male. According to category (5), the schooling effect of JMB is concentrated among the educated young male.

\section{Concluding Remarks}

This study focuses on understanding the structures of poverty reduction effects, specifically job transformation and non-farm employments, of the construction of large infrastructure. Our empirical results suggest that the bridge construction on the Jamuna river that connects the two parts of Bangladesh, facilitated farm to non-farm shift of employments, while also decreasing household unemployment. We also observe specific occupation transition effect according to age, gender and education level. It is, however, not clear though if the improvement in employment prospects reflects an overall gain for Bangladesh from bridge construction, or if it merely implies a displacement of jobs from one area to another. This remains a future area for research.

The results are however suggestive of supply side intervention by government. This means that the government should facilitate opportunities such as public transportation, small business development etc. in order for people to obtain the full benefit of infrastructure investment. For example, evidence suggests that providing cash incentives to aid transportation cost induces seasonal migration, which results in improved household welfare in rural Bangladesh (Bryan et al, 2014). Elsewhere, it has been shown that infrastructure placements have positive impact on property value and help facilitate access to collateral based finance and eventual economic emancipation. Infrastructure placement by itself may 
not be sufficient to maximize the potential benefits. Moreover, since our results indicate that improved infrastructure access induce more schooling, such effects can be strengthened by conditional cash transfer programs to stimulate further human capital investments. However, little is known regarding how much these infrastructure improvements actually change the lives of the poor through other complementary programs. Future research should focus on more rigorous evaluation to quantify the impact of infrastructure provisions combined with social programs as a conduit of poverty reduction in developing countries. 


\section{References}

Al-Hussain, T.M., Mehedi A. A., and Choudhury, J.R. (2004), "Seismic Instrumentation System for Jamuna Bridge," 13th World Conference on Earthquake Engineering, Paper No. 2984, Vancouver, B.C., Canada, August 1-6, 2004

Angrist, J.D., Krueger, A. (1999), Empirical Strategies in Labor Economics, in Hand book of Labor Economics vol.3A, Elsevier, Amsterdam, 1277-1366

Asian Development Bank (2000), Project Completion Report on the Jamuna Bridge Project (Loan 1298-BAN [SF]), Asian Development Bank.

Banerjee, A., Duflo, E. and Qian, N. (2012), On the Road: Access to Transportation Infrastructure and Economic Growth in China, NBER Working Papers

Banerjee, Abhijit V. and Andrew F. Newman (1993), "Occupational Choice and the Process of Development,” Journal of Political Economy 101(21), 274-298.

Barro, R.J. 1990. Government Spending in a Simple Model of Exogenous Growth. Journal of Political Economy 98: 103-125.

Bayes, A. (2007), Impact Assessment of Jamuna Multipurpose Bridge project(JMBP) on Poverty Reduction, Report prepared for the Japan Bank for International Cooperation $(\mathrm{JBIC})$

Bertrand, M., Duflo, E. Mullainathan, S. (2004), How much should we trust differences-in differences estimates? Quarterly Journal of Economics 119, 249-275

Besley, T. and Burgess (2003), Halving Global Poverty, Journal of Economic Perspectives $17(3), 3-22$

Brockerholf, M., and Derose, L. (1996), Child Survival in East Africa: The Impact of Preventive Health Care, World Development 24(12), 1841-1857

Bryan, G., Chowdhury, S., and Mobarak, A.M. (2014), Underinvestment in a Profitable Technology: The case of Seasonal Migration in Bangladesh, Econometrica 82(5), 
$1671-1748$

Calderón, C., E. Moral-Benito, and L. Servén. 2014. Is Infrastructure Capital Productive? A Dynamic Heterogeneous Approach. Journal of Applied Econometrics, forthcoming.

Canning, D. and Bennatham, E. (2000), The social rate of return to infrastructure investments, policy research working paper No 2390, World Bank

Canning, D., and P. Pedroni. 2008. Infrastructure, Long Run Economic Growth, and Causality Tests for Cointegrated Panels. The Manchester School 76(5): 504-527.

Datt, G. and M. Ravallion (1998), Why Have Some Indian States Done better than others at reducing rural poverty? Economica $65,17-38$

DiNardo, John (2008), "Natural experiments and quasi-natural experiments." Steven N. Durlauf and Lawrence E. Blume, eds., the New Palgrave Dictionary of Economics, Second Edition. Palgrave Macmillan.

Dinkelman, T. (2011), The Effects of rural electrification on employment: New Evidence from South Africa, American Economic Review 101(7), 3078-3108

Dollar, D. and Kraay, A. (2002), Growth is good for the poor, Journal of Economic Growth $7(3), 195-225$

Duflo, E., and Pande, R. (2007), Dams, Quarterly Journal of Economics 122(2), 601-646

Esfahani, H, and Ramirez, M. (2003), Institutions, Infrastructure and Economic Growth, Journal of Development Economics 70(2), 443-477

Easterly, W. and Rebelo, S. (1993), Fiscal Policy and Economic Growth: An Empirical Investigation, Journal of Monetary Economics, 32, 417-458.

Fafchamps, M. and Shilpi, F.J. (2005), Cities and Specialization: evidence from South Asia, Economic Journal 115, 477-504

Fan, S. and Zhang, X. (2004), Infrastructure and Regional Economic Development in Rural China, China Economic Review 15(2), 203-214 
Futagami, K., Y. Morita, and A. Shibata. 1993. Dynamic Analysis of an Endogenous Growth Model with Public Capital. Scandinavian Journal of Economics 95: 607-625.

Ghosh, S.C., Rahman, H., and Rana, AKM, M. (2010), Revisiting JAMUNA Bridge Resettlement Areas: Exploring Livelihood Status of the Affected People, BRAC Research Report, September.

Gibson, J, and Rozelle, S. (2003), Poverty and Access to Roads in Papua New Guinea, Economic Development and Cultural Change 52(1), 159-185

Gonzalez-Navarro, M., and Quinana-Domeque, C. (2012), Paving Streets for the Poor: Experimental Analysis of Infrastructure Effects, University of Toronto

Hossain, Mahabub, Binayak Sen, and Yasuyuki Sawada (2012), "Jobs, Growth and Development: Making of the "Other" Bangladesh," a background paper for the World Development Report 2013 Jobs, the World Bank.

Hulten, C.R., Bennathan, E. and S. Srinivasan (2006), Infrastructure, Externalities and Economic Development: A Study of the Indian Manufacturing Industry, The World Bank Economic Review 20(2), 291-308

Jacoby, H., and Minten, B. (2009), On measuring the benefits of lower transport costs, Policy Research Working Paper No. WPS 4484, World Bank

Jacoby, H. (2000), Access to Markets and the Benefits of Rural Roads, Economic Journal 110(465), 713-737

Jalan, J., and Ravallion, M. (2003), Does Piped Water Reduce Diarrhoea for Children in Rural India? Journal of Econometrics 112(1), 153-173

Jimenez, E.Y. (1995), Human and Physical Infrastructure, Handbook of Development Economics, Volume 3B, North Holland, 2773-2843

Khandker, S., Bakht, Z., and Coolwal, G. (2009), The Poverty Impact of Rural Roads: Evidence from Bangladesh, Economic Development and Cultural Change 57(4), 685- 
Lipton, M. and Ravallion, M. (1995), Poverty and Policy, Handbook of Development Economics, Volume 3B, North Holland, 2551-2657

Luppino, M., Gajewski, G., Zohir, S., Khondker, B, and Crowther, D.(2004), Estimating the Impacts of Jamuna Bridge on Poverty levels in Bangladesh using SAM and CGE models; a comparative study, Report prepared by the Luis Berger Group, Washington Lokshin, M. and Yemtsov, R. (2004), Combining Longitudinal Household and Community Surveys for Evaluation of Social Transfers: Infrastructure Rehabilitation Projects in Rural Georgia, Journal of Human Development 5(2), 265-277

Lokshin, M. and Yemtsov, R. (2005), Has rural infrastructure Rehabilitation in Georgia Helped the poor, World Bank Economic Review 19(2): 311-333

Mathiowetz, Nancy A. and Greg J. Duncan (1988), “Out of Work, Out of Mind: Response Errors in Retrospective Report of Unemployment," Journal of Business \& Economic Statistics 6(2), 221-229.

Murphy, K., Shleifer, and Vishny, R.W. (1989), Industrialization and Big Push, Journal of Political Economy 97(5), 1003-1026

Puhani, P.A.(2012), The treatment effect, the cross difference, and the interaction term in non-linear difference-in difference models, Economics Letters 115, 85-87

Ravallion, M. (2001), Growth Inequality and Poverty, Looking Beyond Averages, World Development 29(11), 1803-1815

Sawada, Y. (2014), The Impacts of Infrastructure in Development: A Selective Survey, ADBI Working Paper, Tokyo, Japan.

Van de Walle, D. (1996), Infrastructure and Poverty in Vietnam, LSMS Working Paper No.121. The World Bank, Washington, DC

World Bank (2000), Implementation Completion Report (IDA-25690) on a Credit in the 
Amount of SDR 143.6 Million (US\$ 200.0 Million Equivalent) to the People's Republic of Bangladesh for the Jamuna Bridge Project, Report No: 20587-BD, Infrastructure Sector Unit, South Asia Region, Bangladesh.

Zhang, X, and FAN, S (2004), How Productive is Infrastructure? A New approach and Evidence from Rural India, American Journal of Agricultural Economics 86(2) 
Table 1. Tests of Baseline Covariate Balance

\begin{tabular}{lccc}
\hline \multicolumn{1}{c}{ Variable } & $\begin{array}{c}\text { Treatment } \\
\text { group }\end{array}$ & $\begin{array}{c}\text { Control } \\
\text { group }\end{array}$ & $\begin{array}{c}\text { Mean } \\
\text { difference }\end{array}$ \\
\hline Age of the household head (in 2009) & 51.23 & 51.10 & 0.134 \\
& $(0.500)$ & $(0.447$ & $(0.670)$ \\
$\begin{array}{l}\text { Education level of the household head } \\
\text { (1=illiterate; 2=primary; 3=secondary; 4=post-secondary) }\end{array}$ & 1.50 & 1.49 & 0.010 \\
& $(0.031)$ & $(0.031)$ & $(0.045)$ \\
Proportion of unemployment of the household head & 0.015 & 0.015 & 0.000 \\
& $(0.0046)$ & $(0.0042)$ & $(0.006)$ \\
$\begin{array}{l}\text { Subjective income sufficiency } \\
\text { (1=always deficit; 2=sometime deficit; 3=breakeven; 4=surplus) }\end{array}$ & $(0.032)$ & $(0.031)$ & $(0.045)$ \\
\end{tabular}

Note: Standard errors are in parentheses. 
Table 2. Difference in Difference Regression: Increase in Employment Opportunities

\begin{tabular}{|c|c|c|c|c|}
\hline & $\begin{array}{c}(1) \\
\text { Increased } \\
\text { Employment }\end{array}$ & $\begin{array}{c}(2) \\
\text { Increased } \\
\text { Employment }\end{array}$ & $\begin{array}{c}(3) \\
\text { Increased } \\
\text { Employment }\end{array}$ & $\begin{array}{c}(4) \\
\text { Increased } \\
\text { Employment }\end{array}$ \\
\hline $\bar{D}$ & $\begin{array}{l}0.0401 * \\
(0.0211)\end{array}$ & & $\begin{array}{l}0.0392 * \\
(0.0214)\end{array}$ & \\
\hline Heterogeneous treatment effects & & & & \\
\hline$d$ for Location\#2 in Tangail & & $\begin{array}{l}0.00462 \\
(0.0285)\end{array}$ & & $\begin{array}{l}0.00489 \\
(0.0284)\end{array}$ \\
\hline$d$ for Location\#1 in Sirajganj & & $\begin{array}{c}0.0215 \\
(0.0295)\end{array}$ & & $\begin{array}{c}0.0211 \\
(0.0295)\end{array}$ \\
\hline$d$ for Location\#2 in Sirajganj & & $\begin{array}{l}0.225 * * \\
(0.0975)\end{array}$ & & $\begin{array}{l}0.223 * * \\
(0.0973)\end{array}$ \\
\hline$d$ for Location\#3 in Sirajganj & & $\begin{array}{l}0.0658 * \\
(0.0397)\end{array}$ & & $\begin{array}{c}0.0646 \\
(0.0397)\end{array}$ \\
\hline$d$ for Location\#4 in Sirajganj & & $\begin{array}{c}0.817 * * * \\
(0.0227)\end{array}$ & & $\begin{array}{c}0.817 * * * \\
(0.0230)\end{array}$ \\
\hline$d$ for Location\#3 in Tangail & & $\begin{array}{c}-0.183 * * * \\
(0.0227)\end{array}$ & & $\begin{array}{c}-0.185^{* * * *} \\
(0.0229)\end{array}$ \\
\hline Increase in Land-holding & & & $\begin{array}{c}0.000198 * * \\
(0.0000963)\end{array}$ & $\begin{array}{l}0.000195 * * \\
(0.0000970)\end{array}$ \\
\hline Compensation received & & & $\begin{array}{l}0.0864 \\
(0.213)\end{array}$ & $\begin{array}{l}0.0852 \\
(0.215)\end{array}$ \\
\hline Constant & $\begin{array}{c}0.185 * * * \\
(0.0136)\end{array}$ & $\begin{array}{c}0.183 * * * \\
(0.0227)\end{array}$ & $\begin{array}{c}0.188 * * * \\
(0.0148)\end{array}$ & $\begin{array}{c}0.186 * * * \\
(0.0232)\end{array}$ \\
\hline $\begin{array}{l}\mathrm{N} \\
\text { adj. R-sq }\end{array}$ & $\begin{array}{l}1485 \\
0.002\end{array}$ & $\begin{array}{l}1485 \\
0.006\end{array}$ & $\begin{array}{l}1485 \\
0.002\end{array}$ & $\begin{array}{l}1485 \\
0.007\end{array}$ \\
\hline
\end{tabular}

Note: Standard errors are in parentheses. $* * *, * * * *$ respectively denotes statistical significance at the $1 \%, 5 \%$ and $10 \%$ level. In specifications (2) and (4), Location\#1 in Tangail is taken as a default category for Location dummy variables. 
Table 3. Multinomial Logit (MNL) Model for Job Transition

\begin{tabular}{|c|c|c|c|c|c|}
\hline & (1) & (3) & (5) & (6) & (7) \\
\hline & $\begin{array}{l}\text { coefficient } \\
\text { standard error }\end{array}$ & $\begin{array}{l}\text { coefficient } \\
\text { standard error }\end{array}$ & $\begin{array}{l}\text { coefficient } \\
\text { standard error }\end{array}$ & $\begin{array}{l}\text { coefficient } \\
\text { standard error }\end{array}$ & $\begin{array}{l}\text { coefficient } \\
\text { standard error }\end{array}$ \\
\hline$T \times d$ & $\begin{array}{l}0.090 \\
(0.173) \\
{[0.0412]}\end{array}$ & $\begin{array}{l}-0.354 * \\
(0.200) \\
{[-0.043]}\end{array}$ & $\begin{array}{l}0.012 \\
(0.292) \\
{[0.016]}\end{array}$ & $\begin{array}{l}-0.256 \\
(0.258) \\
{[-0.031]}\end{array}$ & $\begin{array}{c}-0.0351 \\
(0.265) \\
{[0.007]}\end{array}$ \\
\hline$T$ & $\begin{array}{l}0.294 * * * \\
(0.113)\end{array}$ & $\begin{array}{l}1.065^{* * *} * \\
(0.130)\end{array}$ & $\begin{array}{l}-1.964 * * * \\
(0.292)\end{array}$ & $\begin{array}{l}0.656 * * * \\
(0.183)\end{array}$ & $\begin{array}{l}0.653 * * * \\
(0.179)\end{array}$ \\
\hline$d$ & $\begin{array}{l}0.879 * * * \\
(0.120)\end{array}$ & $\begin{array}{l}0.742 * * * \\
(0.150)\end{array}$ & $\begin{array}{l}0.439 * * * \\
(0.130)\end{array}$ & $\begin{array}{l}0.505 * * * \\
(0.162)\end{array}$ & $\begin{array}{l}0.590 * * * \\
(0.193)\end{array}$ \\
\hline Female dummy & $\begin{array}{l}0.711 * * \\
(0.281)\end{array}$ & $\begin{array}{l}1.118^{* * *} * \\
(0.290)\end{array}$ & $\begin{array}{l}3.393 * * * \\
(0.259)\end{array}$ & $\begin{array}{l}9.316^{* * * *} \\
(0.351)\end{array}$ & $\begin{array}{l}3.710 * * * \\
(0.267)\end{array}$ \\
\hline Constant & $\begin{array}{l}-0.065 \\
(0.079)\end{array}$ & $\begin{array}{l}-0.904 * * * \\
(0.102)\end{array}$ & $\begin{array}{l}-0.343 * * * \\
(0.084)\end{array}$ & $\begin{array}{l}-4.523 * * * \\
(0.274)\end{array}$ & $\begin{array}{l}-2.01 * * * \\
(0.139)\end{array}$ \\
\hline
\end{tabular}

Note: Sample size is 7747. Standard errors are in parentheses. Marginal effects calculated at the mean are in brackets. ***,**** respectively denotes statistical significance at the 1\%, 5\% and 10\% level. Occupation categories used for dependent variables are: (1) day labour; (2) farming or fishing (the default category); (3) business and trade (including boatman, tailor, weaver, carpenter, singer, film market, educationalist/learning work, land measuring work/land surveyor, handicraft, mechanic, sewing work/knitwear) (4) abroad (omitted due to too few observations); (5) student; (6) household work; and (7) unemployed/retired. 
Table 4. Multinomial Logit (MNL) Model for Job Transition

(With heterogeneous treatments by age group)

\begin{tabular}{|c|c|c|c|c|c|}
\hline & $\begin{array}{l}\text { (1) } \\
\text { coefficient } \\
\text { standard error }\end{array}$ & $\begin{array}{l}\text { (3) } \\
\text { coefficient } \\
\text { standard error }\end{array}$ & $\begin{array}{l}(5) \\
\text { coefficient } \\
\text { standard error }\end{array}$ & $\begin{array}{l}\text { (6) } \\
\text { coefficient } \\
\text { standard error }\end{array}$ & $\begin{array}{l}(7) \\
\text { coefficient } \\
\text { standard error }\end{array}$ \\
\hline$T \times d$ for age 21 to 30 & $\begin{array}{l}0.780 * * * \\
(0.266) \\
{[0.055]}\end{array}$ & $\begin{array}{l}0.540 * \\
(0.287) \\
{[-0.009]}\end{array}$ & $\begin{array}{l}1.954 * * * \\
(0.352) \\
{[0.025]}\end{array}$ & $\begin{array}{l}0.644^{*} \\
(0.371) \\
{[0.012]}\end{array}$ & $\begin{array}{l}0.521 \\
(0.371) \\
{[-0.012]}\end{array}$ \\
\hline$T \times d$ for age 31 to 50 & $\begin{array}{l}0.343 \\
(0.215) \\
{[0.250]}\end{array}$ & $\begin{array}{l}-0.15 \\
(0.242) \\
{[0.070]}\end{array}$ & $\begin{array}{l}-15.6 \\
(660.1) \\
{[-0.273]}\end{array}$ & $\begin{array}{l}-0.289 \\
(0.332) \\
{[0.050]}\end{array}$ & $\begin{array}{l}-1.474 * * * \\
(0.419) \\
{[-0.159]}\end{array}$ \\
\hline$T \times d$ for age 51 to 71 & $\begin{array}{l}-0.653 * * * \\
(0.209) \\
{[0.080]}\end{array}$ & $\begin{array}{l}-1.353^{* * *} \\
(0.254) \\
{[-0.80]}\end{array}$ & $\begin{array}{l}-16.51 \\
(941.3) \\
{[-0.282]}\end{array}$ & $\begin{array}{l}-1.049 * * * \\
(0.32) \\
{[-0.025]}\end{array}$ & $\begin{array}{l}0.24 \\
(0.294) \\
{[0.196]}\end{array}$ \\
\hline$T$ & $\begin{array}{l}0.294 * * * \\
(0.113)\end{array}$ & $\begin{array}{l}1.064 * * * \\
(0.13)\end{array}$ & $\begin{array}{l}-1.968 * * * \\
(0.194)\end{array}$ & $\begin{array}{l}0.639 * * * \\
(0.183)\end{array}$ & $\begin{array}{l}0.646 \text { *** } \\
(0.18)\end{array}$ \\
\hline$D$ & $\begin{array}{l}0.879 * * * \\
(0.12)\end{array}$ & $\begin{array}{l}0.742^{* * *} \\
(0.15)\end{array}$ & $\begin{array}{l}0.438 * * * \\
(0.13)\end{array}$ & $\begin{array}{l}0.503 * * * \\
(0.162)\end{array}$ & $\begin{array}{l}0.589 * * * \\
(0.193)\end{array}$ \\
\hline Female dummy & $\begin{array}{l}0.689 * * \\
(0.282)\end{array}$ & $\begin{array}{l}1.106^{* * * *} \\
(0.29)\end{array}$ & $\begin{array}{l}3.434 * * * \\
(0.26)\end{array}$ & $\begin{array}{l}9.322 * * * \\
(0.352)\end{array}$ & $\begin{array}{l}3.738 * * * \\
(0.268)\end{array}$ \\
\hline Constant & $\begin{array}{l}-0.0634 \\
(0.0792)\end{array}$ & $\begin{array}{l}-0.902 * * * \\
(0.102)\end{array}$ & $\begin{array}{l}-0.349 * * * \\
(0.0841)\end{array}$ & $\begin{array}{l}-4.501 * * * \\
(0.274)\end{array}$ & $\begin{array}{l}-2.006 * * * \\
(0.14)\end{array}$ \\
\hline
\end{tabular}

Note: Sample size is 7747. Standard errors are in parentheses. Marginal effects calculated at the mean are in brackets. ***,**,* respectively denotes statistical significance at the $1 \%, 5 \%$ and $10 \%$ level. Occupation categories used for dependent variables are: (1) day labour; (2) farming or fishing (the default category); (3) business and trade (including boatman, tailor, weaver, carpenter, singer, film market, educationalist/learning work, land measuring work/land surveyor, handicraft, mechanic, sewing work/knitwear) (4) abroad (omitted due to too few observations); (5) student; (6) household work; and (7) unemployed/retired. 
Table 5. Multinomial Logit (MNL) Model for Job Transition

(With heterogeneous treatments by age group and gender)

\begin{tabular}{|c|c|c|c|c|c|}
\hline & $\begin{array}{l}1) \\
\text { coefficient } \\
\text { standard error }\end{array}$ & $\begin{array}{l}(3) \\
\text { coefficient } \\
\text { standard error }\end{array}$ & $\begin{array}{l}\text { (5) } \\
\text { coefficient } \\
\text { standard error }\end{array}$ & $\begin{array}{l}(6) \\
\text { coefficient } \\
\text { standard error }\end{array}$ & $\begin{array}{l}7) \\
\text { coefficient } \\
\text { standard error }\end{array}$ \\
\hline$T \times d$ for male age 21 to 30 & $\begin{array}{l}0.745 * * * \\
(0.267) \\
{[0.472]}\end{array}$ & $\begin{array}{l}0.502 * \\
(0.289) \\
{[0.254]}\end{array}$ & $\begin{array}{l}2.130 * * * \\
(0.356) \\
{[0.057]}\end{array}$ & $\begin{array}{l}-12.87 \\
(639.4) \\
{[-1.106]}\end{array}$ & $\begin{array}{l}0.671^{*} \\
(0.384) \\
{[0.262]}\end{array}$ \\
\hline$T \times d$ for male age 31 to 50 & $\begin{array}{l}0.363^{*} \\
(0.217) \\
{[0.762]}\end{array}$ & $\begin{array}{l}-0.131 \\
(0.245) \\
{[0.388]}\end{array}$ & $\begin{array}{l}-16.74 \\
(1626.2) \\
{[-0.313]}\end{array}$ & $\begin{array}{l}-13.98 \\
(778.6) \\
{[-1.097]}\end{array}$ & $\begin{array}{l}-1.430 * * * \\
(0.524) \\
{[0.078]}\end{array}$ \\
\hline$T \times d$ for male age 51 to 71 & $\begin{array}{l}-0.662 * * * \\
(0.211) \\
{[0.091]}\end{array}$ & $\begin{array}{l}-1.356 * * * \\
(0.258) \\
{[-1.001]}\end{array}$ & $\begin{array}{l}-16.95 \\
(1490) \\
{[-0.336]}\end{array}$ & $\begin{array}{l}-1.045 \\
(1.058) \\
{[-0.011]}\end{array}$ & $\begin{array}{l}0.361 \\
(0.302) \\
{[0.265]}\end{array}$ \\
\hline$T \times d$ for female age 21 to 30 & $\begin{array}{l}14.14 \\
(1079.5) \\
{[0.654]}\end{array}$ & $\begin{array}{l}{[13.75]} \\
(1079.5) \\
{[0.340]}\end{array}$ & $\begin{array}{l}13.93 \\
(1079.5) \\
{[0.034]}\end{array}$ & $\begin{array}{l}13.31 \\
(1079.5) \\
{[0.093]}\end{array}$ & $\begin{array}{l}12.83 \\
(1079.5) \\
{[0.114]}\end{array}$ \\
\hline$T \times d$ for female age 31 to 50 & $\begin{array}{l}-0.162 \\
(0.852) \\
{[0.299]}\end{array}$ & $\begin{array}{l}-0.623 \\
(0.875) \\
{[0.090]}\end{array}$ & $\begin{array}{l}-16.06 \\
(951.2) \\
{[-0.315]}\end{array}$ & $\begin{array}{l}-0.746 \\
(0.79) \\
{[0.024]}\end{array}$ & $\begin{array}{l}-1.986 * * \\
(0.896) \\
{[-0.201]}\end{array}$ \\
\hline$T \times d$ for female age 51 to 71 & $\begin{array}{l}-0.672 \\
(0.891) \\
{[0.178]}\end{array}$ & $\begin{array}{l}-1.604 \\
(0.987) \\
{[-0.098]}\end{array}$ & $\begin{array}{l}-16.64 \\
(1271.4) \\
{[-0.324]}\end{array}$ & $\begin{array}{l}-1.541 * \\
(0.792) \\
{[-0.033]}\end{array}$ & $\begin{array}{l}-0.411 \\
(0.819) \\
{[0.159]}\end{array}$ \\
\hline$T$ & $\begin{array}{l}0.293 * * * \\
(0.113)\end{array}$ & $\begin{array}{l}1.063 * * * \\
(0.13)\end{array}$ & $\begin{array}{l}-1.974 * * * \\
(0.195)\end{array}$ & $\begin{array}{l}0.611 * * * \\
(0.185)\end{array}$ & $\begin{array}{l}0.641 * * * \\
(0.181)\end{array}$ \\
\hline$D$ & $\begin{array}{l}0.878^{* * * *} \\
(0.12)\end{array}$ & $\begin{array}{l}0.742 * * * \\
(0.15)\end{array}$ & $\begin{array}{l}0.437 * * * \\
(0.13)\end{array}$ & $\begin{array}{l}0.499 * * * \\
(0.163)\end{array}$ & $\begin{array}{l}0.588 * * * \\
(0.194)\end{array}$ \\
\hline Female dummy & $\begin{array}{l}0.661^{* *} \\
(0.33)\end{array}$ & $\begin{array}{l}1.103 * * * \\
(0.34)\end{array}$ & $\begin{array}{l}3.549 * * * \\
(0.293)\end{array}$ & $\begin{array}{l}9.208 * * * \\
(0.382)\end{array}$ & $\begin{array}{l}3.896 * * * \\
(0.306)\end{array}$ \\
\hline Constant & $\begin{array}{l}-0.0607 \\
(0.0793)\end{array}$ & $\begin{array}{l}-0.898 * * * \\
(0.102)\end{array}$ & $\begin{array}{l}-0.360 * * * \\
(0.0845)\end{array}$ & $\begin{array}{l}-4.298 * * * \\
(0.28)\end{array}$ & $\begin{array}{l}-2.039 * * * \\
(0.143)\end{array}$ \\
\hline
\end{tabular}

Note: Sample size is 7747. Standard errors are in parentheses. Marginal effects calculated at the mean are in brackets. $* * *, * * *$ respectively denotes statistical significance at the $1 \%, 5 \%$ and $10 \%$ level. Occupation categories used for dependent variables are: (1) day labour; (2) farming or fishing (the default category); (3) business and trade (including boatman, tailor, weaver, carpenter, singer, film market, educationalist/learning work, land measuring work/land surveyor, handicraft, mechanic, sewing work/knitwear) (4) abroad (omitted due to too few observations); (5) student; (6) household work; and (7) unemployed/retired. 
Table 6. Multinomial Logit (MNL) Model for Job Transition

(With heterogeneous treatments by age group, gender, and education level)

\begin{tabular}{|c|c|c|c|c|c|}
\hline & $(1)$ & (3) & (5) & (6) & (7) \\
\hline \multirow[t]{3}{*}{$T \times d$ for male age 21 to 30} & $0.892 * * *$ & -0.0673 & -0.55 & -18.84 & -0.508 \\
\hline & $(0.303)$ & $(0.343)$ & (0.779) & (1312.1) & $(0.502)$ \\
\hline & [1.400] & [0.742] & {$[0.020]$} & {$[-2.885]$} & {$[0.252]$} \\
\hline \multirow[t]{3}{*}{$T \times d$ for male age 31 to 50} & $0.497 * *$ & $-0.596 * *$ & -17.56 & -19.32 & $-1.761 * * *$ \\
\hline & $(0.226)$ & $(0.268)$ & (2206.4) & (1056.4) & $(0.521)$ \\
\hline & [1.464] & {$[0.755]$} & {$[-0.100]$} & {$[-2.866]$} & {$[0.191]$} \\
\hline \multirow[t]{3}{*}{$T \times d$ for male age 51 to 71} & $-0.493 * *$ & $-1.717 * * *$ & -17.8 & $-5.750 * * *$ & -0.114 \\
\hline & $(0.219)$ & $(0.292)$ & (2085.2) & (1.017) & $(0.302)$ \\
\hline & [0.432] & [0.013] & {$[-0.117]$} & {$[-0.736]$} & {$[0.152]$} \\
\hline \multirow{3}{*}{$\begin{array}{l}T \times d \text { for male age } 21 \text { to } 30 \\
\text { (high education group) }\end{array}$} & -0.665 & $1.214 * *$ & $3.429 * * *$ & 0.327 & $1.446^{* *}$ \\
\hline & $(0.501)$ & $(0.5)$ & $(0.862)$ & $(2135.2)$ & $(0.652)$ \\
\hline & {$[-0.318]$} & {$[0.218]$} & {$[0.023]$} & [0.009] & [0.107] \\
\hline \multirow{3}{*}{$\begin{array}{l}T \times d \text { for male age } 31 \text { to } 50 \\
\text { (high education group) }\end{array}$} & $-2.467 * * *$ & $1.546^{* * *}$ & -4.912 & -4.912 & -22.59 \\
\hline & $(0.711)$ & $(0.455)$ & $(61521.1)$ & $(29455.5)$ & (86145.6) \\
\hline & [0.347] & [1.175] & {$[-0.010]$} & {$[-0.262]$} & {$[-1.755]$} \\
\hline \multirow{3}{*}{$\begin{array}{l}T \times d \text { for male age } 51 \text { to } 71 \\
\text { (high education group) }\end{array}$} & $-3.115^{* * *}$ & $1.190 * * *$ & -1.09 & -14.9 & -0.107 \\
\hline & $(1.054)$ & $(0.441)$ & (8108.6) & (3751.7) & $(0.52)$ \\
\hline & [0.147] & [1.105] & [0.018] & {$[-2.100]$} & [0.316] \\
\hline \multirow[t]{3}{*}{$T \times d$ for female age 21 to 30} & 16.05 & 14.29 & 1.321 & 18.48 & 17.15 \\
\hline & (2020.3) & (2020.3) & (3017.8) & (2020.3) & (2020.3) \\
\hline & {$[0.773]$} & {$[0.124]$} & {$[-0.091]$} & [0.875] & [0.312] \\
\hline \multirow[t]{3}{*}{$T \times d$ for female age 31 to 50} & 0.487 & -0.0158 & -13.73 & $3.489 * * *$ & $1.417 *$ \\
\hline & $(0.788)$ & $(0.854)$ & (1453.4) & $(0.72)$ & $(0.845)$ \\
\hline & {$[-0.118]$} & {$[-0.199]$} & {$[-0.107]$} & {$[0.491]$} & {$[0.053]$} \\
\hline \multirow[t]{3}{*}{$T \times d$ for female age 51 to 71} & -0.0239 & -0.932 & -14.29 & $2.741 * * *$ & $2.992 * * *$ \\
\hline & $(0.829)$ & (1.014) & (1921.4) & $(0.722)$ & $(0.762)$ \\
\hline & {$[-0.161]$} & {$[-0.323]$} & {$[-0.108]$} & {$[0.424]$} & {$[0.233]$} \\
\hline \multirow{3}{*}{$\begin{array}{l}T \times d \text { for female age } 21 \text { to } 30 \\
\text { (high education group) }\end{array}$} & -16.65 & 2.188 & 17.62 & -0.172 & -0.338 \\
\hline & $(3960.1)$ & $(3370.5)$ & (4047.9) & $(3370.5)$ & (3370.5) \\
\hline & {$[-3.919]$} & [1.687] & {$[0.166]$} & [0.903] & [0.433] \\
\hline \multirow{3}{*}{$\begin{array}{l}T \times d \text { for female age } 31 \text { to } 50 \\
\text { (high education group) }\end{array}$} & -1.088 & 17.02 & 15.05 & 15 & -1.981 \\
\hline & $(5708.8)$ & (4521.9) & (6909.2) & (4521.9) & (8359.2) \\
\hline & {$[-2.498]$} & {$[2.497]$} & {$[0.064]$} & [1.610] & {$[-0.761]$} \\
\hline \multirow{3}{*}{$\begin{array}{l}T \times d \text { for female age } 51 \text { to } 71 \\
\text { (high education group) }\end{array}$} & -0.577 & 18.43 & 15.61 & 15.59 & -3.557 \\
\hline & $(12674.6)$ & $(10039.6)$ & $(15119.2)$ & $(10039.6)$ & $(18559.2)$ \\
\hline & {$[-2.484]$} & [2.717] & {$[0.065]$} & [1.632] & {$[-0.949]$} \\
\hline \multirow[t]{2}{*}{$T$} & $0.288^{* *}$ & $1.054 * * *$ & $-2.075^{* * *}$ & $0.326 * * *$ & $0.516^{* * *}$ \\
\hline & $(0.113)$ & $(0.13)$ & $(0.187)$ & $(0.0945)$ & $(0.167)$ \\
\hline \multirow[t]{2}{*}{$D$} & $0.878 * * *$ & $0.740 * * *$ & $0.420 * * *$ & $0.455^{* * *}$ & $0.568 * * *$ \\
\hline & $(0.12)$ & $(0.15)$ & $(0.121)$ & $(0.107)$ & $(0.185)$ \\
\hline \multirow[t]{2}{*}{ Constant } & -0.0435 & $-0.862 * * *$ & $0.126^{*}$ & $0.925^{* * *}$ & $-1.402 * * *$ \\
\hline & $(0.0788)$ & $(0.101)$ & $(0.0756)$ & $(0.0651)$ & \\
\hline
\end{tabular}

Note: Sample size is 7747. Standard errors are in parentheses. Marginal effects calculated at the mean are in brackets. $* * * * * * *$ respectively denotes statistical significance at the 1\%,5\% and 10\% level. Occupation categories used for dependent variables are: (1) day labour; (2) farming or fishing (the default category); (3) business and trade (including boatman, tailor, weaver, carpenter, singer, film market, educationalist/learning work, land measuring work/land surveyor, handicraft, mechanic, sewing work/knitwear) (4) abroad (omitted due to too few observations); (5) student; (6) household work; and (7) unemployed/retired. 
Figure 1. Impact of Jamuna Bridge: Location of Treatment and Control Areas

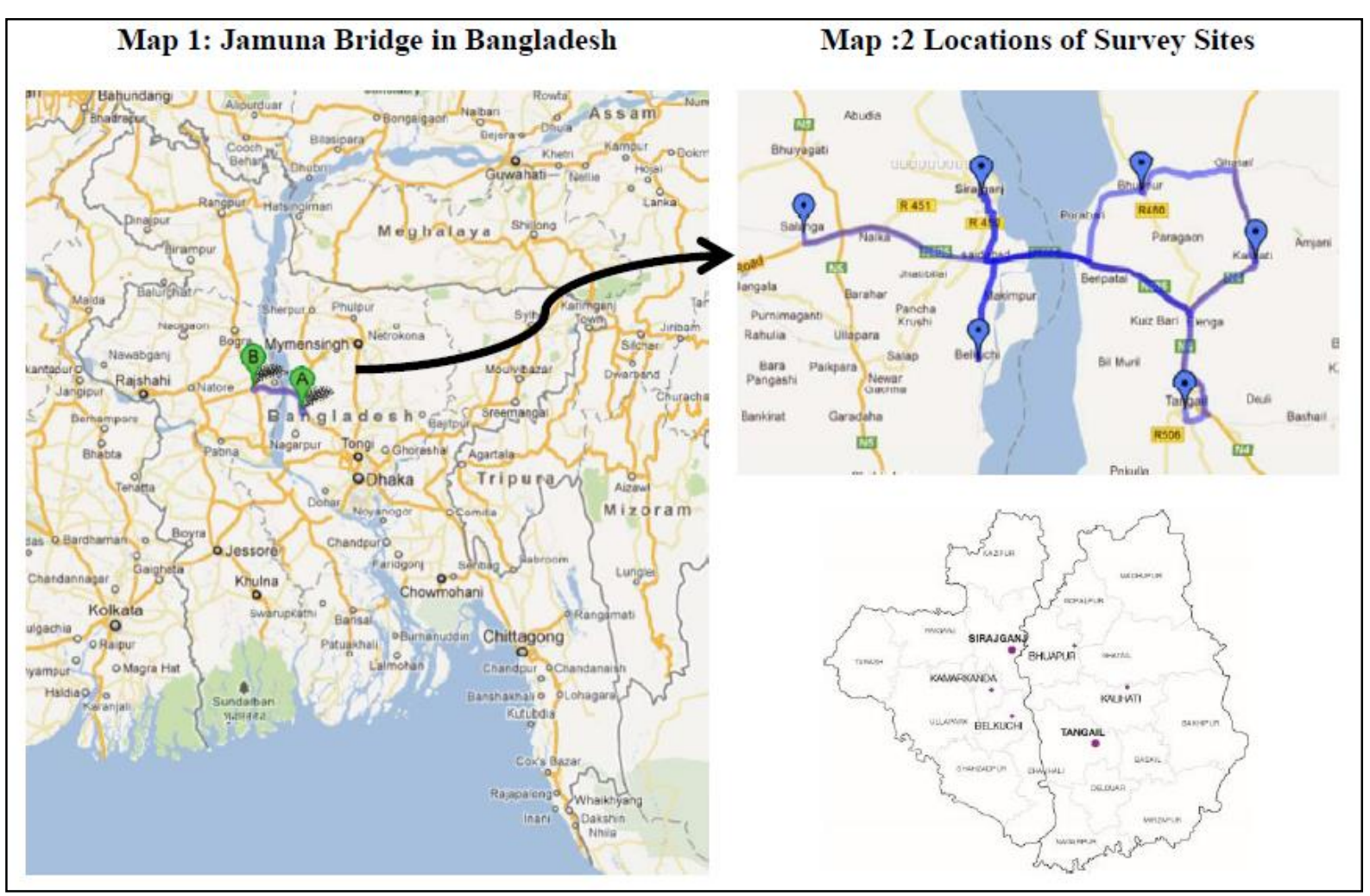


Annex-1

Transition Matrix of Job Categories for Tangail

Before JMB (Rows) and After JMB (Columns)

(Frequency and Cell Percentage)

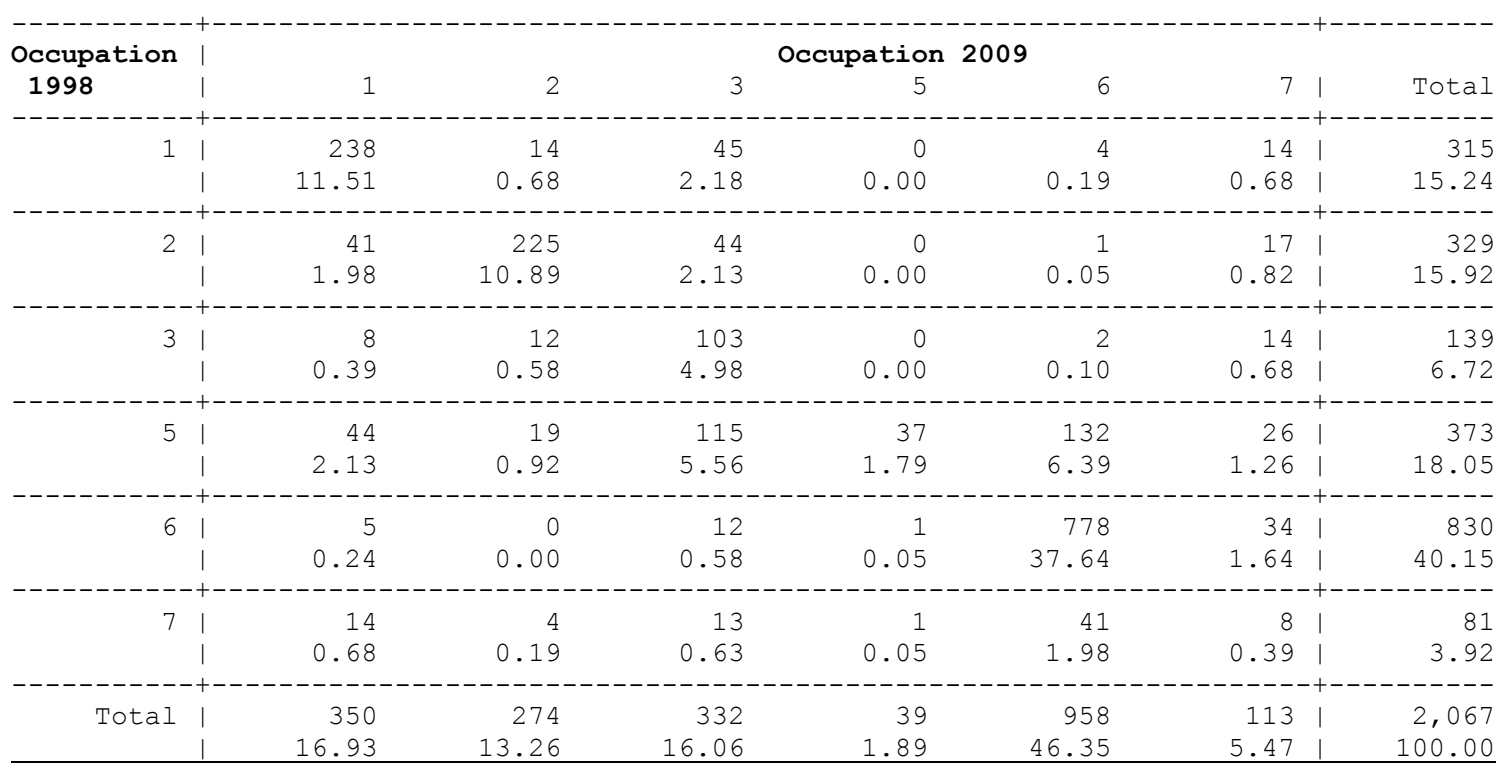

Codes: (1) Day labour; (2) Farming or fishing; (3) Business and service (including boatman, tailor, weaver, carpenter, singer, film market, educationalist/learning work, land measuring work/land surveyor, handicraft, mechanic, sewing work/knitwear) (4) Abroad (omitted due to only single observation); (5) Student; (6) Household work; (7) Unemployed/retired.

Annex-2

Transition matrix of job categories for Sirajganj

Before JMB (Rows) and After JMB (Columns)

(Frequency and Cell Percentage)

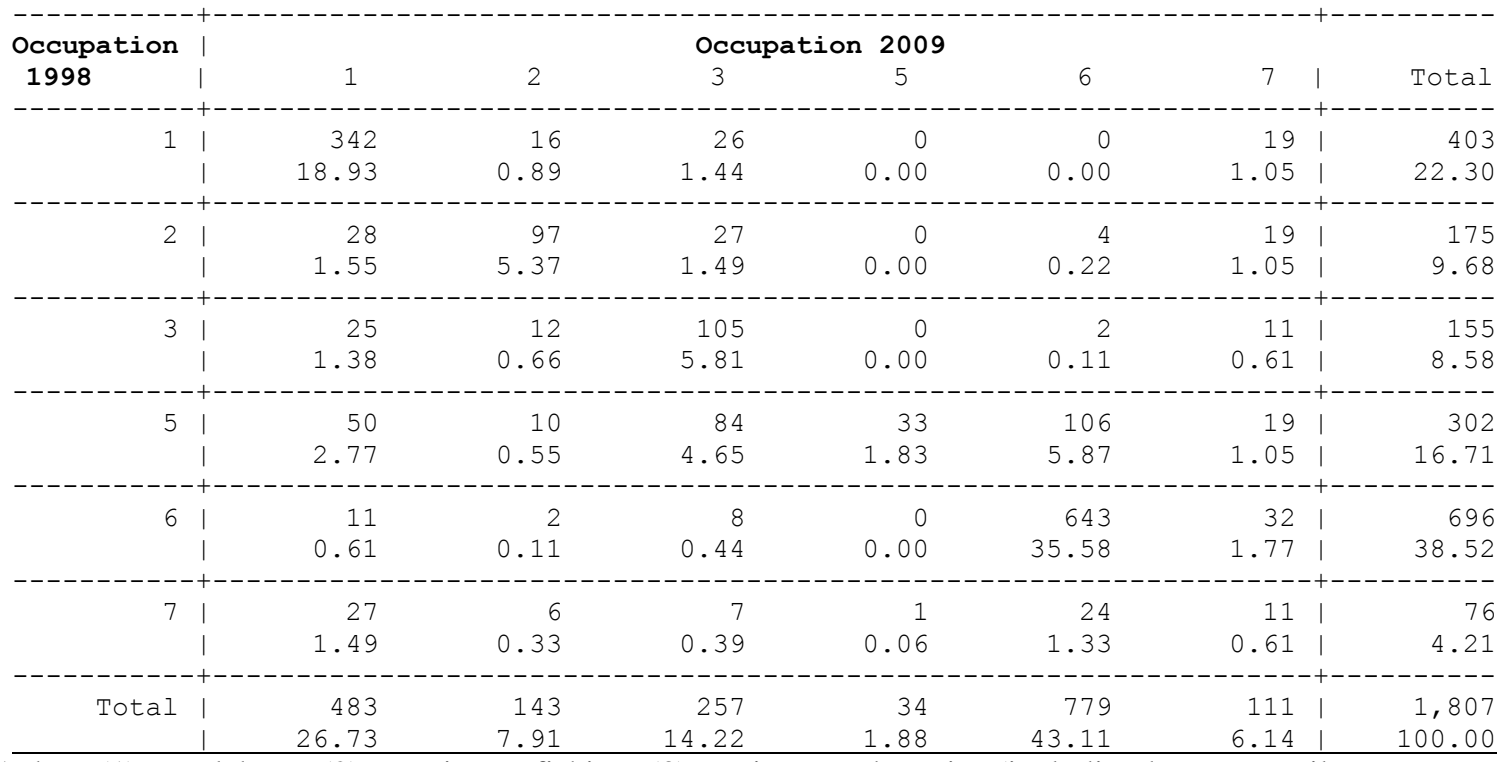

Codes: (1) Day labour; (2) Farming or fishing; (3) Business and service (including boatman, tailor, weaver, carpenter, singer, film market, educationalist/learning work, land measuring work/land surveyor, handicraft, mechanic, sewing work/knitwear) (4) Abroad (omitted due to only single observation); (5) Student; (6) Household work; (7)

Unemployed/retired. 